\title{
Effect of Use Different Eggs with Different Techniques of Salted Eggs on the level of Consumer Preference
}

\author{
Selvia Tharukliling ${ }^{(1)} \&$ Zaenal Fanani ${ }^{(2)}$ \\ ${ }^{1}$ STIPER Santo Thomas Aquinas, Jayapura, ${ }^{2}$ Universitas Brawijaya \\ E-mail: 'selvia_stiper@yahoo.co.id,2prof_zaenalfanani@yahoo.co.id,
}

Received: 13 February 2018; Revised: 19 April 2018; Accepted: 8 May 2018

\begin{abstract}
Abstrack
This study aims to determine the effect of different types of eggs and salting techniques on making salted eggs to the level of consumer preference. Types of eggs used are duck eggs, laying chicken eggs and local chicken eggs. The three types of eggs will be in use by using the method of immersion and wrapping. This study used a completely randomized design with $2 \times 3$ factorial pattern with 3 replications to obtain 18 experimental units. The variables observed in this study are the color of egg yolk, egg texture, salty egg taste, and the level of consumer preference. Based on the results of the research results obtained for variables yellow eggs have a significant effect $(p<0.01)$ with the highest value in duck eggs with the technique of wrapping and then in the duck eggs by immersion techniques while the chicken eggs and eggs on the eggs obtained results which is not much different. Next to the texture of salted eggs the results have no real effect but the highest value remains in duck eggs with wrapping technique. In taste ariable results have a significant effect $(p<0.01)$ on the taste of salted eggs and the best results are on duck eggs with packaging techniques. The last variable is the level of consumer preferences to the salted eggs results have a significant effect on the level of consumers with the highest value on duck eggs with immersion techniques. Of the four variables can be concluded that the results showed the highest and best value according to the consumer is a salted egg from duck eggs with immersion techniques.
\end{abstract}

Key words: egg salting, salting method, egg type,

\section{Introduction}

Technology applications have enabled improvements in the living standards of many humans in different parts of the world, this has also led to an increase in resource consumption and waste production. technology is often part of problem solving and creates many opportunities and at the same time technology is also the cause of environmental problems (Fanani, 2017). In relation to the application of such technology in the world of livestock, especially in the processing of livestock, there is a simple technology that is commonly used by traditional poultry farmers (ducks, poultry, chicken race) when abundant egg harvesting technique commonly made in salted eggs from duck eggs Salted egg products are popular because of its benefits, among others, can extend the shelf life and maintain the quality of eggs and nutritional content, can reduce the risk of damage to the eggs due to rupture either in the process of packing or in the process of transportation, the form of serving egg products 
that have a lot of taste in the community and can increase the selling price of eggs.

Ducks have long maintained in rural areas. Maintenance is commonly done to date by the breeder is the traditional way, that is by ranch of ducks in the fields or in places with lots of water. A duck within a year can produce 203 eggs / year of eggs when kept in stanchion while traditionally maintained yields of only 124 grains / year. (Rangkuti, 1990). Largebodied chicken breeds have fast growth, high meat and egg production, thick flesh and large eggs, and have a feed conversion (conversion) into a high protein (meat and egg) product compared to domestic poultry. Laying chickens start laying eggs at the age of 5 months and egg production reaches 250 eggs / year, and the egg weight ranges from 50-60 grams (Samadi, 2010).

According to the study of poultry experts, chicken breeding (buras) traditionally produce eggs as much as 30-50 grains / head / year. However, with good maintenance the production can be increased to 125-150 eggs / head / year, with an average egg weight of 43.6 grams / grains. The productivity of chickens (buras) with traditional maintenance only reaches $19.03 \%$ every day, but with improved management and genetic quality improvement, production can be increased between $41.3 \%$ to $54.35 \%$. (Larasati, 2010) To reduce the number of egg damage when the eggs are abundant in the market it is necessary preservation of eggs to maintain the quality of eggs in order to survive longer or not quickly damaged. For that required the technique of egg processing as an effort to improve the quality of eggs to be preferred by consumers. Pickling duck eggs, chicken eggs, chicken (buras) aims to extend the shelf life and provide good taste to consumers. Extending the savings of fresh eggs in principle to treat the whole eggs so that the pores are not entered by microbes. In addition, the treatment also aims to prevent the release of $\mathrm{CO} 2$ and water from the egg. (Sudaryani, 2006).

The process of preservation of eggs one of them by egg salting method that can be done in two ways namely the first way through immersion of eggs in salt solution of choice, the procedure begins by soaking the quality eggs in a salt solution that has been cold temperature. Length of immersion about 7-10 days. This method is the method of making salted eggs easy and simple. However, the quality of the resulting flavor is quite good (Anonymous, 2013). The second way with the method of wrapping, can be by using salt and rubbing ash or with salt and clay dough. How to marinating this process by mixing the basic ingredients and add enough water, after the dough is ready and then do the wrapping of eggs that have been prepared. Storage duration for 14 days. This method will produce salted eggs much better quality, more attractive color, and taste better (Anonymous, 2013) from the above explanation will be conducted research on the influence of eggs and different techniques of egg marinating to the level of consumer preferences.

\section{Material and Methods}

This research has been conducted in the laboratory of Animal Production Technology Department of Livestock Agriculture High School of St. Thomas Aquinas Jayapura for 2 weeks from December 2 to December 16, 2017. The tools used in this research are as follows: Electric scales, plastic containers, egg try, plates and spoons, while the material used is 36 duck eggs, 36 eggs, 36 chicken eggs (buras) as much as 36 grains, 12 packs of rubbing, 12 packs of salt, enough water, mineral water, and cucumbers. Marinating techniques used are the technique of wrapping and immersion techniques. Procedure in the wrapping technique is to make salt and ash dough with a ratio of 1: 2 then all types of eggs wrapped / wrapped with batter and arranged in a basin container and then stored for 12 days. For the immersion technique the procedure is to make a saturated salt solution then each type of egg is arranged in different jars then saturated salt solution in the pour slowly samapai cover egg solution to prevent floating in the solution then on the surface of the egg on the press with a plastic that contains water to egg the position of the meeting in the jar and jar closed and kept for 12 days.

This study used a Completely Randomized Design (RAL) with $2 \times 3$ factorial pattern with 3 replications so that 18 units of experiments were obtained. Treatment used for factor A (egg type) $\mathrm{A} 1=$ Rice eggs $\mathrm{A} 2=$ Egg eggs A $3=$ Eggs factor $\mathrm{B}$ (salting technique) $\mathrm{B} 1=$ Immersion Technique 
B2 $=$ Technique of wrapping The variables observed are Color yolk, Texture egg, taste of salted egg, favorite level (tested with hedonic scale according to susiwi, 2009). The data obtained will be analyzed with further variance if the treatment showed a real effect, then continued with the smallest real difference test (BNT) Gazper

\section{Results and Discussion}

Eggs used for salted eggs in this study are duck eggs, laying chicken eggs, local chicken eggs are processed by using a system or immersion technique and wrapping, where the content of salt in eggs can produce microorganisms and produce a distinctive aroma and can be stored for long periods of time. Based on the results of the research then obtained the data that is the result of organoleptic test of 12 panelists. The following will be described one by one results in research variables based on the results of variance.

\section{Effect of Use of Eggs and Different Marinat- ing Techniques on Egg Yellow Colors to the level of consumer preference}

From the result of the research through organoleptic test resulted the average of analysis for the color of salted egg as listed in table below:
Based on the results of anova table analysis above for the type of eggs with immersion techniques to get results for R1 (laying chicken) against R2 (local chicken) is not significantly different but for R3 (duck egg) the results are significantly different with R1 and R2. While for the type of egg with the same result of wrapping technique that is $\mathrm{R} 1$ to $\mathrm{R} 2$ is not real different but for R3 the result is significantly different to R1 and R2. This means that consumers based on egg yolk prefer eggs type on the treatment of R3 (duck egg) with packaging technique. The process of marinating the duck eggs with the wrapping technique produces a reddish color similar to the yolk color in the duck egg that is commonly marinated, being on the eggs of the chicken and the yellow color of the egg yellow to the orange.

The results of this study show the egg yolk color is somewhat different because basically the yolk color there is a pale yellow, dark yellow to orange. This difference depends on the type of feed given. The yolk color is influenced by the pigment found in the plant in the form of grain that feeds poultry, the pigment is called xanthophylis. color is a visual character that can be judged by the eye, so if the presentation of food less attractive will reduce consumer interest. (Anonymous, 2013).

Table 1 value rate analysis for Salted Egg Colors

\begin{tabular}{|l|c|c|c|}
\hline \multirow{2}{*}{$\begin{array}{c}\text { technique of salted } \\
\text { egg }\end{array}$} & \multicolumn{3}{|c|}{ kinds of egg } \\
\cline { 2 - 4 } & R1 (laying chicken) & R2 (local chicken) & R3 (Duck) \\
\hline Immersion salt & $2.60^{\mathrm{a}}$ & $2.60^{\mathrm{a}}$ & $6.03^{\mathrm{b}}$ \\
\hline wrapping salt & $3.00^{\mathrm{a}}$ & $3.03^{\mathrm{a}}$ & $8.63^{\mathrm{c}}$ \\
\hline
\end{tabular}

Information : Superscripts of different values show a significant effect.

Table 2 Value rate analysis for salted eggs textur

\begin{tabular}{|c|c|c|c|}
\hline \multirow{2}{*}{$\begin{array}{c}\text { technique of salted } \\
\text { egg }\end{array}$} & R1 (laying chicken) & R2 (local chicken) & R3 (Duck) \\
\cline { 2 - 4 } & 9.67 & 9.53 & 10.17 \\
\hline saline solution & 9.90 & 9.53 & 10.67 \\
\hline wrapping salt & & & \\
\hline
\end{tabular}

Information : Superscripts of different values show a significant effect 
The Effect of Using Eggs and Different Marinating Techniques on Egg flavor to consumer's level of preferences

From the results of the research through organoleptic test, the average analysis for salty egg taste as listed in the table 2,

Based on the results of anova table analysis, the results obtained for the type of eggs used did not significantly affect the texture of salted eggs so that no further tests were conducted. Similarly, the marinating technique with the method of immersion and wrapping also showed results that were not significantly different. But if seen from the average then the duck egg has the highest value compared to chicken eggs and chicken eggs are 10.17 for immersion techniques and 10.67 for packaging techniques. Texture is a very important characteristic for salted egg products. Because salted egg products are elastic and tasty. Usually the texture is related to the tenderness and hardness of the product.

\section{Effect of Using Eggs and Different Marinat- ing Techniques to the level of consumer pref- erence}

Based on the results of anova table analysis then, obtained results for the type of eggs used both R1, R2 and R3 showed results that have no significant effect. But the immersion technique showed a distinctly different result in which the consumer prefers the result of salted egg by using the technique of wrapping in the immersion appeal. This occurs because of the difference in the thickness of the eggshell where the duck eggs have a thicker shell in the appeal with the eggs of chicken and the poultry so that when done taste flavoring techniques obtained in the duck eggs more tasty and preferably the consumer.

According to (Munir and Sintawati,
2014) Duck eggs are generally processed into salted eggs, because they have characteristics suitable for processing into salted eggs that have lower water content and fat content higher than chicken eggs. Low water levels make duck egg whites become more supple and high fat content makes the yolk more masir. The principle of making salted egg is the ionization process of $\mathrm{Na}+$ and $\mathrm{Cl}$ ions that diffuses into the egg through the pores of the shell. The salting result is highly dependent on the concentration of salt given and the speed of salt diffusion into the egg. Preferred salted eggs are salted eggs with egg whites that are not too salty, but egg yolk masirFaktor very determine a product acceptable or not by the consumer is a taste. Giving salt according to Belitz and Grosch (2009) in munir and sintawati, 2014. has an effect on protein solubility. Giving too little (low concentration) will increase protein solubility (salting effect) by suppressing the interaction of electrostatic proteinproteins, whereas too much salt (high concentration) will decrease protein solubility (salting out effect) as a result of the hydration tendency of salt ions. in relation to the level of consumer preference despite good. assessment parameters, but if it feels disliked, then the product will be rejected (Soekarto, 1985 in Susiwi, 2009. Making salted eggs in Indonesia generally still scale home industry, to be more advanced in need strategy improvement in terms of marketing and product innovation such as research conducted by Aman, Fanani and Nugroho, 2016. To the Hilo company in order to get a positive response from consumers then one of the strategies undertaken is to create new innovations in the product to have a more sense strong, so that consumers have a more positive attitude toward the taste attribute owned by Hilo's milk.

Table 3 Value rate analysis for salted eggs flavour

\begin{tabular}{|c|c|c|c|}
\hline \multirow{2}{*}{$\begin{array}{c}\text { technique of salted } \\
\text { egg }\end{array}$} & R1 (layer chicken) & R2 (local chicken) & R3 (Duck) \\
\cline { 2 - 4 } & $6.17^{\mathrm{a}}$ & $6.17^{\mathrm{a}}$ & $7.57^{\mathrm{a}}$ \\
\hline saline solution & $6.57^{\mathrm{a}}$ & $6.77^{\mathrm{a}}$ & $9.67^{\mathrm{b}}$ \\
\hline wrapping salt & & & \\
\hline
\end{tabular}

Information : Superscripts of different values show a significant effect 
Effect of Using Eggs and Different Marinating Techniques to the level of consumer preference

From the result of the research through organoleptic test resulted the average of analysis for consumer likes level as stated in tabeel below consumer perception of product selection decision is also obtained, that the quality variable is the most dominant product attributes affect the student in the decision of product selection Antangin $\mathrm{JRG}^{\circledR}$ tablet.

Table 4 Value rate analysis for salted eggs flavour

\begin{tabular}{|c|c|c|c|}
\hline \multirow{2}{*}{$\begin{array}{c}\text { technique of salted } \\
\text { egg }\end{array}$} & R1 (layer chicken) & R2 (local chicken) & R3 (Duck) \\
\cline { 2 - 4 } & $5.10^{\mathrm{a}}$ & $6.30^{\mathrm{a}}$ & $9.10^{\mathrm{b}}$ \\
\hline saline solution & $6.04^{\mathrm{a}}$ & $6.70^{\mathrm{a}}$ & $10.10^{\mathrm{b}}$ \\
\hline wrapping salt & &
\end{tabular}

Information : Superscripts of different values show a significant effect

Based on the results of anova table analysis, the results obtained for the type of eggs in use turned out very different very real to the level of consumer preferences where R3 (duck egg) obtained the highest point that is on R3.2 (wrapping technique with value: 10.10 and immersion techniques R3.1 with the value: 9.10), followed by R1 (eggs of chicken) on the packaging technique (R1.2) with the value of 7.30, R2. (Chicken eggs) on the packaging technique (R2.2) with the value: $6.70, \mathrm{R} 2.1$ on immersion technique with value: 6.30 , and lowest point on R1.1 immersion technique with value: 5.10. From the results of the research, consumers prefer R3 (duck egg) on the technique of wrapping and immersion technique, followed by R1 (eggs of chicken) on packaging technique, R2 (chicken eggs) on the technique of wrapping and immersion techniques, and less favored by consumers on R1 (chicken eggs) on immersion techniques.

According to Suroto, Fanani and Nugroho (2013) The process of consumer decision making generally includes five stages, namely the introduction of needs, information search, alternative evaluation, purchasing and purchasing evaluation. Consumer behavior can be defined as activities related to the acquisition, consumption and release of goods or services, which also includes decision-making processes before and after the event. Factors that influence consumer buying behavior may include culture, social, personal and psychological. In the research on

\section{Conclusion}

Salted eggs preferred by consumers based on the results of research is duck eggs on the wrapping technique because the color is more interesting, the texture is preferred by consumers and the taste is more delicious and delicious. from the results of research can be seen that there is no calculation of the economic value of the manufacture of salted eggs of the three types of eggs and two marinating techniques, so further research is needed on the economic value in using chicken eggs, chicken eggs and duck eggs on salted eggs.

\section{Reference}

Anonymous., 2013. special salted eggs noble juice. (Online) brebes.muliasari brebes.blogspot. com

Amam, Zaenal Fanani, Bambang Ali Nugroho, 2016. Analysis of Consumer Attitudes Against High Calcium Powder Milk Using Multiple Attributes Model and Subjective Norms Model. Discourse, 19(2).

Fanani, Z., N, T.P., \& Rosita, V. 2016. Effect of consumer perception on Antangin Product Selection Decision JRG@ tablet. Indonesia Journal of Pharmacy, 1(1).

Fanani, Z. 2017. Sustainable Development. Malang: Dream Litera.

Gaspers. V., 1991. Experimental Design Method. Bandung: CV. Armico. 
Haryono., 2000. Technical measures of egg quality test of chicken consumption. Bantinak: Litbang Deptan.

Hardini, S. 2000. The influence of temperature and duration of consumption egg storage and biological eggs on interior quality of chicken eggs. Jakarta: Deptan

Larasati, A., 2010. smart breeding of laying hens and broiler, New Library Press. Yogyakarta.

Munir, I.M., \& Sintawati, R. 2014. Uji Organoleptik Telur Asin dengan Konsentrasi Garam dan Masa Peram Yang Berbeda. Seminar Nasional Teknologi Peternakan dan Veteriner, Malang.

Murtidjo. 1988. Manages ducks. Yogyakarta: Kanisus.

Rangkuti, M. 1990. Livestock Technical Information. Research and Development Center.

Sudaryani. T. 2006. Egg Quality. Jakarta: PT. The Swadaya Spreader.

Susiwi, S. 2009. Organoleptic Assessment Hand out feed regulation courses, Bandung: UPI

Suroto, S., Fanani, Z., \& Nugroho, B.A. 2013. Factors influencing consumer's purchase decision of formula milk in Malang City. IOSR Journal of Business and Management, 9(3).

Warisno. 2005. Makes Salted Eggs of Various Flavors. Jakarta: PT. Adromedia Library. 